American Journal of Environmental Sciences 7 (3): 237-243, 2011

ISSN 1553-345X

(C) 2011 Science Publications

\title{
A Field Study of the Fates of Arsenal and Escort Applied on the Cumberland Plateau in Tennessee
}

\author{
${ }^{1}$ John Harwood and ${ }^{2}$ Rong Jiang \\ ${ }^{1}$ Department of Chemistry, Tennessee Technological University, \\ Cookeville, TN, USA \\ ${ }^{2}$ Department of Environmental Sciences and Engineering, \\ Gillings School of Global Public Health, \\ University of North Carolina at Chapel Hill, Chapel Hill, NC 27599
}

\begin{abstract}
Problem statement: The low organic soils of the Cumberland Plateau, as well as the karst geology of the region, may promote increased transport of herbicides outside of application sites. We have studied the fates of imazapyr and metsulfuron-methyl applied to a privately owned tract on the Cumberland Plateau in Tennessee and compared the field results with herbicide fate predicted by the computer model GLEAMS. Approach: The fate of the two herbicides, applied for pine release at a site on the Cumberland Plateau, was monitored over a sixteen month period. Concentrations in soil water were monitored using vacuum soil lysimeters. Grab samples were taken of water in ephemeral streams draining the clearcut area and of a perennial stream which receives water from the study area. Uncut streamside management zones of about $50 \mathrm{~m}$ bordered the streams. The field results were compared with those obtained using the GLEAMS computer model. Results: Concentrations of both herbicides in soil water dropped significantly within the first two months after application, imazapyr to less than $50 \mu \mathrm{g} \mathrm{L}^{-1}$ and metsulfuron-methyl to less than $3 \mu \mathrm{g} \mathrm{L}^{-1}$ and decreased more gradually in the following months. The maximum concentrations observed in soil water were $252 \mu \mathrm{g} \mathrm{L}^{-1}$ (imazapyr) and $13 \mu \mathrm{g}$ $\mathrm{L}^{-1}$ (metsulfuron-methyl). Except on two dates occurring 5 months after application, the herbicides were not detected in the stream samples. GLEAMS predicted that very little herbicide should have been lost from the site in runoff or erosion sediment. The model predicted greater retention of the herbicides by the soil than was found through the field measurements. Conclusion/Recommendation: The rapid transport of imazapyr and metsulfuron we observed indicates that further study is justified at other locations on the Cumberland Plateau. Streamside management zones effectively prohibited contamination of receiving streams by herbicides at the study site.
\end{abstract}

Key words: Imazapyr, metsulfuron-methyl, GLEAMS, pine release, alkaline, southeastern, lysimeter, cumberland plateau, contaminate, Laurel Creek (LC), Soil Organic Matter (SOM)

\section{INTRODUCTION}

Imazapyr and metsulfuron-methyl are herbicides which are used worldwide in a variety of applications. They are the active ingredients in Arsenal, Chopper and Assault herbicides and in Escort and Ally herbicides, respectively. These herbicides are commonly used in forest management in the southeastern United States. Though belonging to different pesticide families (imazapyr is classified as an imidazolinone, while metsulfuron-methyl is classified as a sulfonylurea herbicide), they share many characteristics (Cox, 1996; Oregon State University, 1993). Both are ionic and water soluble, making them potentially mobile in soil and both are found to be generally non-toxic to animals, fish and insects. One reason for the nontoxicity of the compounds is that they share a mode of action, the inhibition of the production of branched amino acids, which interrupts a metabolic pathway active only in plants.

Imazapyr is slowly degraded by microbes and can be relatively persistent in soils. Because it does not bind strongly with soil or sediment, imazapyr can be highly mobile in the environment and therefore may contaminate water. Reported soil half-lives of imazapyr range from 1-5 months. Imazapyr has been found both

Corresponding Author:John Harwood, Department of Chemistry, Tennessee Technological University, Cookeville, TN, USA Tel: $38505,931372-3473$ 
in surface and ground water following forestry applications (Cox, 1996; Michael and Neary, 1993). The compound undergoes photodegradation in water with a half-life of about 2 days.

Metsulfuron-methyl is broken down through chemical hydrolysis (Oregon State University, 1993). It is stable to hydrolysis at neutral and alkaline $\mathrm{pH}$. Reported soil half-lives of metsulfuron-methyl range from 14-180 days. The water solubility of metsulfuron-methyl is increased at higher $\mathrm{pH}(\mathrm{pH}=$ 4.6, $270 \mathrm{mg} \mathrm{L}^{-1} ; \mathrm{pH}=5.4,1750 \mathrm{mg} \mathrm{L}^{-1} ; \mathrm{pH}=6.7$, $9500 \mathrm{mg} \mathrm{L}^{-1}$ ). Thus, metsulfuron-methyl is more mobile and more stable in alkaline soils than in acidic soils. It is classified as highly mobile in soil.

While research has been conducted on the fate of herbicides used in forest ecosystems in the southeastern United States (Michael and Neary, 1993; Neary et al., 1993), to date there has been no reported investigation focusing on the unique conditions of the Cumberland Plateau. The soils on the Cumberland Plateau have low organic matter content, which may limit their ability to retain herbicides. The karst geology of the region, which allows ready mixing of surface and groundwater, may promote increased transport of herbicides outside of application sites.

The GLEAMS computer model (Groundwater Loading Effects of Agricultural Management Systems) is a hydrological model developed by the United States Department of Agriculture. GLEAMS simulates edge-of-field and bottom-of-root-zone loadings of water and chemicals from complex climate-soil-management interactions (Shirmohammadi et al., 2001). The model tracks the fate of pesticides in runoff, on eroded sediment and in percolation water (below the bottom of the effective rooting depth).

We have studied the fates of imazapyr and metsulfuron-methyl applied to a privately owned tract on the Cumberland Plateau on Tennessee. Over a twoyear period, we monitored concentrations of the pesticides in site soil and receiving stream waters. A unique in-line pre-concentration High Performance Liquid Chromatography (HPLC) analytical method was developed for the study. In this study we present the results of our study and compare the results with herbicide fate predicted by the computer model GLEAMS.

\section{MATERIALS AND METHODS}

Site description and sampling: A privately owned tract on Gross Ridge ( $35^{\circ} 50^{\prime} 12^{\prime \prime} \mathrm{N}, 85^{\circ} 18^{\prime} 01^{\prime \prime} \mathrm{W}$ ), directly east of Virgin Falls Pocket Wilderness in White County, TN, was chosen as our study site. About 24 hectare $(60$ acres) of the tract was clearcut in 2002 and was planted with pine in late spring 2004.

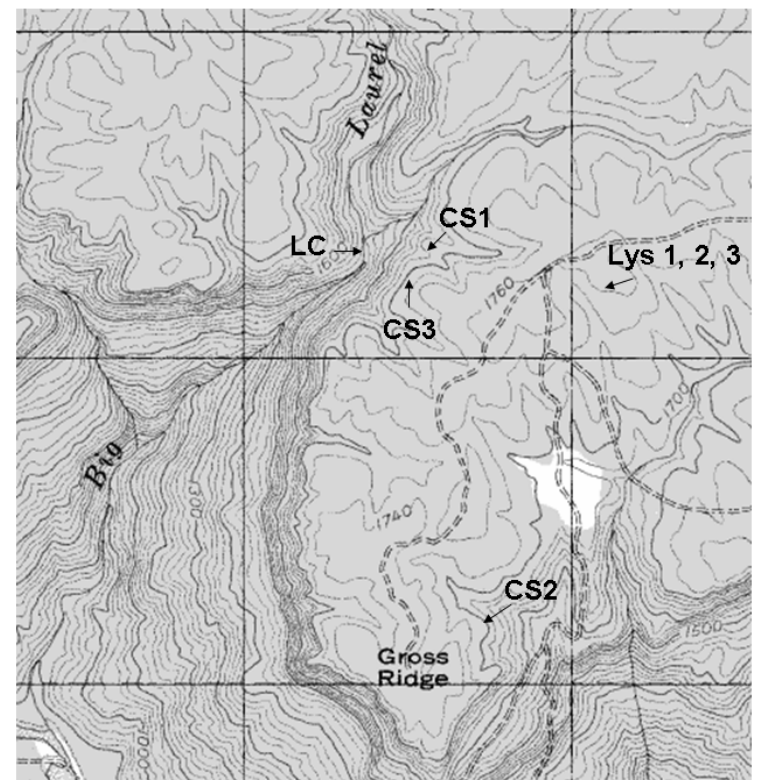

Fig. 1: Map of field sampling sites at Gross Ridge, in White County, Tennessee $\left(35^{\circ} 50^{\prime} 12^{\prime} \mathrm{N}, 85^{\circ}\right.$ 18 ' 01 ” W)

The clearcut area is at the top of the ridge, extending from approximately 536-524 m (1760-1720 feet) elevation. Arsenal and Escort were aerial sprayed for pine release on October 5, 2004. The application rate was $0.84 \mathrm{~kg}$ active ingredient per hectare $\left(\mathrm{kg}\right.$ a.i. $\left.\mathrm{h}^{-1}\right)$ of imazapyr and $0.07 \mathrm{~kg}$ a.i. $\mathrm{h}^{-1}$ of metsulfuron-methyl.

Besides soil water samples, three small ephemeral streams, labeled CS1, CS2, CS3 (Fig. 1) and one perennial stream, big Laurel Creek (LC), were selected for surface water grab sampling. The CS sites are ephemeral streams produced by drainage from the surrounding clearcut area. The uncut "streamside management zones" of these catchments are ample, about $50 \mathrm{~m}$ in width. Big Laurel Creek is at the base of a naturally wooded ravine along one side of the clearcut area.

Three small stainless steel vacuum lysimeters (Model SW-074, Soil Measurement Systems, Tucson, AZ), fitted with Teflon tubing, were installed September 1,2004 . The lysimeters were set at different depths in holes made with a $6.98 \mathrm{~cm}(2-3 / 4$ in) diameter auger (Edelman One-Piece Auger, Eijkelkamp Agrisearch Equipment BV, Giesbeek, The Netherlands). The lysimeters were set at the bottom of individual soil layers as indicated by visual observation of the augured soil cores. The depths of the bottoms of the lysimeters were: Lys 1, $69 \mathrm{~cm}$; Lys 2, $40 \mathrm{~cm}$ and Lys 3, $25 \mathrm{~cm}$. Slurries of the original soil layers were used to imbed the 
lysimeters; the holes were plugged at the top with 10 cm layer of bentonite slurry. Lys 1 and Lys 2 were positioned adjacent to one another, $1.5 \mathrm{~m}$ apart, in a portion of the clearcut free of any residual vegetation; Lys 3 was placed about $4 \mathrm{~m}$ from these two, in an area which retained low vegetation.

The first sampling date was on September 18, 2004. Sampling was generally weekly, on the day following each successive rain event. Approximately 1 inch of rainfall was found necessary to allow subsequent collection of sufficient water from the lysimeters for analysis. Soil water samples were generally of small volume $(5-150 \mathrm{~mL})$ and after the preliminary samplings (before herbicide application) it was decided to increase sample volume by allowing the lysimeter vacuum pump to operate overnight, generally for a period of $18 \mathrm{~h}$.

Samples were collected in $250 \mathrm{~mL}$ amber glass bottles with Teflon-lined caps (Fisher Scientific, Hampton, NH). The bottles containing sample were stored for transport in a cooler chilled with frozen cool packs. Spiked samples were prepared on-site by adding sample to aliquots of stock herbicide solutions transported to the site in the sample bottles. Blank and recovery check samples were also prepared in the laboratory with Type I water (Milli-Q Ultrapure Water Purification System, Millipore, Billerica, MA).

In the laboratory, sample $\mathrm{pH}$ was measured and samples were syringe-filtered through $0.45 \mathrm{~mm}$ PTFE filters (FisherBrand, Fisher Scientific, Hampton, NH) into Teflon-lined capped vials and stored at $4{ }^{\circ} \mathrm{C}$ until analysis. All samples were analyzed within three days and generally within $24 \mathrm{~h}$, after sampling and preparation.

Sample analysis: Samples were analyzed with an inline pre-concentration HPLC method developed for the study. Chromatography was performed on a Varian ProStar HPLC-Photodiode Array HPLC. A delivery pump (Model 110A, Beckman Coulter, Fullerton, CA) was used to deliver samples to the pre-concentration column (Synergi $4 \mathrm{~m}$ Hydro-RP 80A, $4 \mu \mathrm{m}$ particle diameter, $30 \times 4.60 \mathrm{~mm}$, Phenomenex, Torrance, CA). Reverse-phase analytical HPLC columns were used to achieve sample separation (Spherex 5 C18, $5 \mu \mathrm{m}$ particle diameter, $250 \times 4.60 \mathrm{~mm}$, Phenomenex, Torrance, $\mathrm{CA}$, or $\mu$ Bondapak $\mathrm{C} 18,10 \mu \mathrm{m}$ particle diameter, $300 \times 3.9 \mathrm{~mm}$, Waters Corporation, Milford, MA). Five $\mathrm{mL}$ samples were loaded onto the pre-column at a flow rate of $2.5 \mathrm{~mL} \min ^{-1}$ prior to analysis. Analysis was performed with a mobile phase of $45 \%$ acetonitrile and $55,0.2 \%$ (v:v) concentrated phosphoric acid with a flow rate of $1.5 \mathrm{~mL} \mathrm{~min}^{-1}$.
An analytical wavelength of $230 \mathrm{~nm}$ was used. The detection limits, determined as three times the standard deviation of baseline noise of water "blank" sample, for the herbicides were: imazapyr-0.05 $\mu \mathrm{g} \quad \mathrm{L}^{-1}$ and metsulfuron-methyl $-0.12 \mu \mathrm{g} \mathrm{L}^{-1}$.

Modeling: Soil texture was determined by the ASTM D 422 hydrometric method (ASTM International, 2000). Soil Organic Matter (SOM) was determined by redox titration following digestion of soil samples with dichromate (Radojevic and Bashkin, 1999). Other soil characteristics were based on Soil Survey of White and Van Buren County, TN (Prater, 1981).

The precipitation and other climatic parameters were obtained from Crossville weather station (The Weather Underground, 2006), which is located on the Cumberland Plateau about 16 miles from the study site. For metsulfuron-methyl, a water solubility of 9,500 mg $\mathrm{L}^{-1}$ was used, appropriate for the measured $\mathrm{pH}$ of the lysimeter samples.

\section{RESULTS}

Field measurements: Generally, neither of the applied herbicides was found in any of the stream water samples. On March 8, 2005, 5 months after application, imazapyr was tentatively identified, based on chromatographic retention time and UV spectra, to be present in CS1, CS2 and LC samples at 16, 43 and 44 $\mu \mathrm{g} \mathrm{L}^{-1}$, respectively (Fig. 1 for sampling locations). Metsulfuron-methyl was also tentatively identified in the CS2 sample on this date, at a concentration below our quantitation limit (measured at $1 \mu \mathrm{g} \mathrm{L}{ }^{-1}$ ). The CS3 stream was not running on this sampling date. No evidence of either compound was found in the preceding set of samples (1/9/2005) and on the next sampling date $(3 / 25 / 2005)$ only the CS2 sample showed any indication of containing imazapyr and this at a level too low to be positively identified by the UV spectrum. Very low concentration component peaks occurred in the chromatograms for stream samples which in some cases had retention times coincident with that of imazapyr, however these peaks could not be positively identified with the UV photodiode array detector.

The maximum measured concentrations of imazapyr and metsulfuron-methyl in soil water (lysimeter) were 265 and $14 \mu^{-1} \mathrm{~L}$, respectively (Fig. 2 and 3). The concentrations of imazapyr in soil water decreased to below $50 \mu \mathrm{g} \mathrm{L}^{-1}$ within three months after application and that of metsulfuron-methyl to below $3 \mu \mathrm{g} \mathrm{L}^{-1}$ in a somewhat shorter time. Imazapyr was in higher concentration in soil water than was metsulfuron-methyl. 
Am. J. Environ. Sci., 7 (3): 237-243, 2011

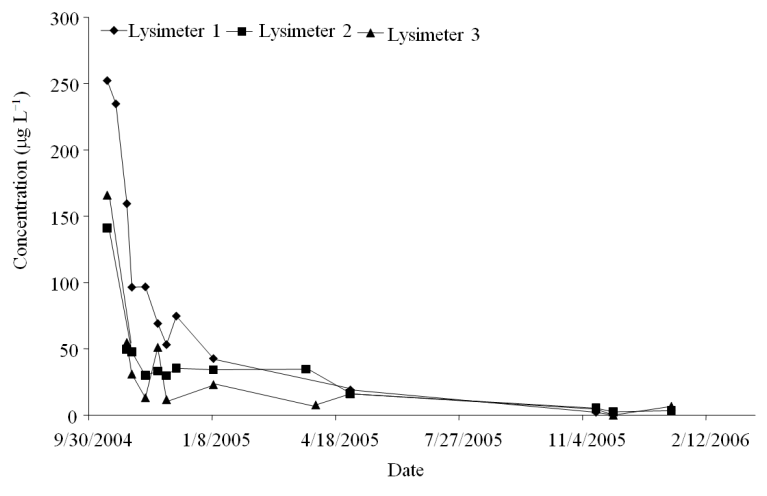

Fig. 2: Imazapyr in soil water

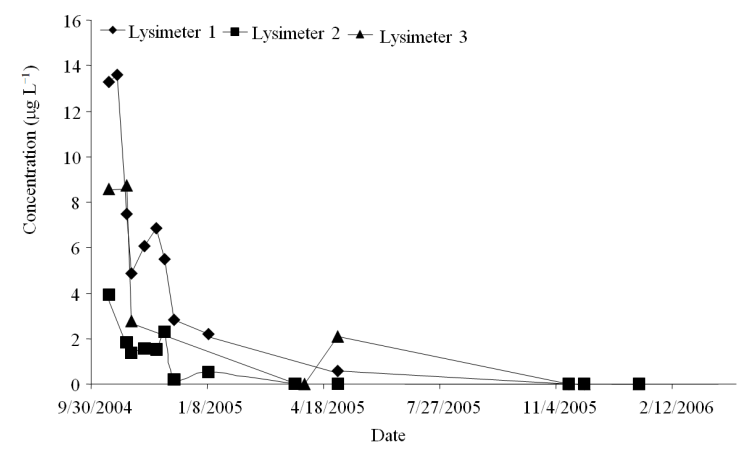

Fig. 3: Metsulfuron-methyl in soil water

Comparing concentrations obtained with the three lysimeters, the relative concentrations were consistent for the two herbicides; however, the relative concentrations were not consistent with depth of lysimeter placement. The depths of lysimeters were in the order of Lys3 < Lys2 < Lys1. Water from Lysimeter 1 had the highest concentrations of herbicides in the initial few samples. Concentrations in water obtained with Lysimeter 3 were intermediate in the initial samples.

The concentrations of metsulfuron-methyl in soil water samples were much lower than those of imazapyr. This is expected both because the application rate of imazapyr was 12 times higher than that of metsulfuron-methyl and, as noted above, imazapyr is more persistent in soil than is metsulfuron-methyl (soil half-life 1-5 months and 14-180 days, respectively).

The $\mathrm{pH}$ of soil water samples was higher than that of the surface water samples. With the exception of one LC sample, which had a $\mathrm{pH}$ of 6.38 , stream water $\mathrm{pH}$ ranged between 4.05 and 5.50. Lys 1 and Lys 2 soil water $\mathrm{pH}$ ranged between 5.80 and 6.69; Lys 3 soil water samples had higher $\mathrm{pH}$, between 7.10 and 7.68.

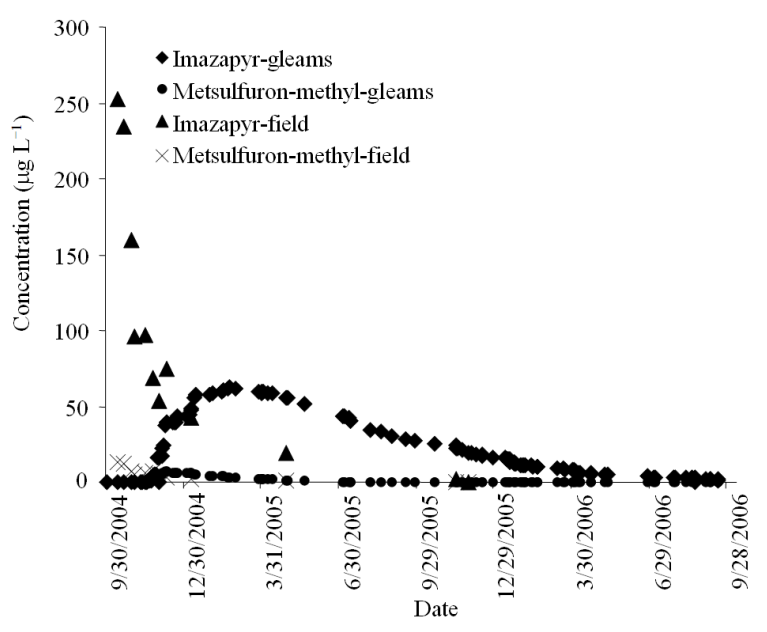

Fig. 4: GLEAMS and field results for soil water, Lysimeter 1

Table 1: Soil texture and organic carbon (SOM) of Lysimeter 1 soils

\begin{tabular}{llllll}
\hline Depth $(\mathrm{cm})$ & Silt $(\%)$ & Clay $(\%)$ & Sand $(\%)$ & Texture & SOM $(\%)$ \\
\hline 10 & 39.0 & 13.8 & 47.2 & Loam & 2.90 \\
21 & 42.9 & 15.8 & 41.3 & Loam & 1.45 \\
42 & 45.5 & 18.8 & 35.7 & Loam & 0.51 \\
63 & 23.4 & 49.5 & 27.1 & Clay & 0.35 \\
\hline
\end{tabular}

GLEAMS modeling: The soil of Lysimeter 1 was chosen for modeling with GLEAMS. Soil organic matter content and soil texture were measured (Table 1). The Munsill Color index for this soil is: $0-15 \mathrm{~cm}$, 7.5YR 4/2; $15-40 \mathrm{~cm}, 7.5$ YR 5/3; 40-75 cm, 2.5 YR 5/8 and below $75 \mathrm{~cm}, 10 \mathrm{R} 4 / 8$.

The measured profiles of percolation of the herbicides differed from those predicted by GLEAMS (Fig. 4). The concentrations shown predicted by GLEAMS shown in Fig. 4 correspond to those in percolation water exiting the "rooting depth", set at 63 $\mathrm{cm}$ (the depth of the center of Lysimeter 1). GLEAMS predicted the first appreciable losses would occur on November 30, 2004, about 2 months after application. This date is that of an intense precipitation event with $7.39 \mathrm{~cm}$ rainfall; the second largest rainfall during this period was $3.51 \mathrm{~cm}$. Our field measurements found no corresponding delay in percolation of the herbicides following application.

GLEAMS also predicted longer time would be required for the herbicides to percolate out of the soil. In the case of imazapyr, about 24 months (after application) were required by the model for percolation water concentrations to drop below $1 \mu \mathrm{g} \mathrm{L}^{-1}$; about 7 months were required in the case of metsulfuron-methyl to drop to this level. Our field results show that concentrations of the herbicides in soil dropped more 
quickly to low levels. We found imazapyr concentration dropped below $1 \mu \mathrm{g} \mathrm{L}^{-1}$ about 14 months after application and metsulfuron-methyl dropped to this level about 5 months after application.

Modeling indicated that most transport of the herbicides would have occurred in soil percolation water. GLEAMS predicts the herbicides would have been present in runoff surface water, but at a very low level ( $<0.05 \%$ of applied). GLEAMS predicts loss of both herbicides in sediment to have been $<0.01 \%$. The concentration of imazapyr in percolation water was found to be much higher than that of metsulfuron-methyl using both methods. The simulated concentrations in leaching water were similar in magnitude to the detected level for each herbicide.

\section{DISCUSSION}

Rapid movement of metsulfuron-methyl in soil, as we found to occur at the Cumberland Plateau study site, has been reported for several soils and in glacial till subsoil (Heistermann et al., 2003; Jorgensen et al., 2002; Ismail and Tet-Vun, 2003). The organic carbon and other components of the soil at our study site exhibited very low affinity in retaining the herbicides. The rapid transport through the soil may also be attributed to "multi-domain" flow, or movement of water through "macro-pores" in the soil produced by earthworms, decaying roots and other sources (Heistermann et al., 2003; Jorgensen et al., 2002). As noted in the introduction, imazapyr and metsulfuron-methyl are similar in terms of soil retention and water solubility, hence the similar rate of transport observed for the two compounds is expected.

The relative concentrations of herbicides in soil waters sampled with the different lysimeters is not directly correlated with the depth of lysimeter placement on most sampling dates. The highest concentrations of both herbicides were observed in soil water obtained with the most deeply placed lysimeter (Lysimeter 1, bottom placement $69 \mathrm{~cm}$ ), while the least deeply placed lysimeter produced soil water with intermediate concentration (Lysimeter 3, bottom placement $25 \mathrm{~cm}$ ). The herbicides moved very rapidly with each rain event and it may be that the highest concentration zones of herbicides moved past the more shallowly placed lysimeters during the first rain event. Also, while the soils around all three lysimeters were similar, the layering and detailed characteristics of the soils around the individual lysimeters varied, which may have caused some variation in retention of the herbicides. The surface around Lysimeter 3 was covered with grass and other low vegetation, which could have caused some delay in transport of herbicide into the soil; the other two lysimeters were placed in an area with no surface vegetation. The variation in relative concentrations of herbicides measured at the different depths is actually rather small and the primary conclusion obtained from all the data is that imazapyr and metsulfuron-methyl both move very quickly through the loam soil studied.

Despite their high mobility in the soil, the herbicides were not observed to contaminate the receiving streams. This is no doubt the result of the large streamside management zones, about $50 \mathrm{~m}$, on both sides of the streams. In Alabama, imazapyr was found in surface water following aerial application at both of two forestry sites studied (Michael and Neary, 1993). The peak stream concentration was $0.130 \mathrm{mg}$ $\mathrm{L}^{-1}$ where a streamside management zone was employed and $0.680 \mathrm{mg} \mathrm{L}^{-1}$ without the zone. In the Pacific Northwest, imazapyr was found in surface water in one out of two sites monitored by the Washington Department of Ecology following aerial forestry applications (Cox, 1996). In a recent, unpublished study performed in eastern Texas, Loucha et al. (2005) observed imazapyr to contaminate surface water at concentrations up to about $40 \mu \mathrm{g} \mathrm{L}^{-1}$ despite the presence of $50 \mathrm{ft}$ streamside management zones.

Metsulfuron-methyl concentrations in the soil water were much less than those of imazapyr. This difference is greater than can be attributed to the difference in application rates of the two herbicides and is likely the result of more rapid degradation of metsulfuron-methyl in the soil, through chemical hydrolysis. Concentrations of both herbicides dropped significantly, to less than $50 \mu \mathrm{g} \mathrm{L}^{-1}$ (imazapyr) and 3 $\mu \mathrm{g} \mathrm{L}^{-1}$ (metsulfuron-methyl) within the first two months after application and decreased more gradually in the following months. The maximum concentrations observed in soil water were $252 \mu \mathrm{g} \mathrm{L}^{-1}$ (imazapyr) and $13 \mu \mathrm{g} \mathrm{L}{ }^{-1}$ (metsulfuron-methyl).

Recommendations: The rapid transport of imazapyr and metsulfuron through the Cumberland Plateau soil which we observed in our study indicates that further study is justified. Transport and persistence of the herbicides at other locations on the Cumberland Plateau should be investigated. While we found little evidence of transport through the stream management zones present at our field site, it seems likely that transport off site will occur, potentially leading to contamination of surface waters at other sites. More study is needed to 
establish the minimum width of stream management zones necessary to contain these herbicides. The discrepancies between modeling and field results may be due to the presence of macropores in the soil, not accounted for by GLEAMS. Further research on forestry applications could calibrate models which can simulate macropore transport, such as Macro (Nicholas and Larsson, 2000; Imnek et al., 2003) or Rzwqm (Malone et al., 2003).

\section{CONCLUSION}

In a fresh clearcut on the Tennessee Cumberland Plateau, we found metsulfuron-methyl and imazapyr to move quickly through the soil, with levels in soil water dropping significantly within the first two months after application. Relatively lower concentrations found of metsulfuron-methyl indicate that this herbicide was being more rapidly degraded in the soil. The GLEAMS computer model significantly underestimates the rate of transport of the herbicides in this setting. A $50 \mathrm{~m}$ vegetated streamside management zone was effective in greatly reducing transport of herbicide offsite.

\section{ACKNOWLEDGEMENT}

The researchers wish to thank Manuel Campoamor for graciously furnishing the site used in this study. This study was funded by the Tennessee Technological University Faculty Research Program.

\section{REFERENCES}

ASTM International, 2000. ASTM D 422 Standard Test Method for Particle-Size Analysis of Soils. In: ASTM Annual Book of Standards, West Coushohocken, PA. (Ed.). ASTM International, pp: 10-12. ISBN: 0-8031-2780-4

Cox, C., 1996. Herbicide factsheet imazapyr. J. Pest. Reform., 16: 16-20. http://www.pesticide.org/getthe-facts/pesticide-factsheets/factsheets/imazapyr

Heistermann, M., B. Jene, G. Fent and M. Feyerabend et al., 2003. Modeling approaches to compare sorption and degradation of metsulfuron-methyl in laboratory micro-lysimeter and batch experiments. Pest Manage. Sci., 59: 1273-1290. DOI: 10.1002/ps.765

Imnek, J., N.J. Jarvis, M.T. Genuchten and A. Gärdenäs, 2003. Review and comparison of models for describing non-equilibrium and preferential flow and transport in the vadose zone. J. Hydrol.,
272: 14-35. DOI: 10.1016/S0022-1694(02)00252-4

Ismail, B.S. and C. Tet-Vun, 2003. A field study on persistence and mobility of metsulfuron-methyl in three tropical agricultural soils. Austral. J. Soil Res., 41: 27-35. DOI: 10.1071/SR01107

Jorgensen, P.R., M. Hoffmann, J.P. Kistrup, C. Bryde and R. Bossi et al., 2002. Preferential flow and pesticide transport in a clay-rich till: Field, laboratory and modeling analysis. Water Resour. Res., 38: 1-15. DOI: 10.1029/2001WR000494

Loucha, J., M. McBroomb, B. Gowinc, J. Shepardd and G. Allena et al., 2005. Herbicide concentrations in surface waters associated with different forestry management intensities and best management practices. Proceeding of the 5th International Conference on Forest Vegetation Management June 20-24, Corvallis, Oregon. http://outreach.cof.orst.edu/icfvm/PPt/Louch.pdf\#s earch='HERBICIDE $\% 20$ CONCENTRATIONS $\% 2$ OIN\%20SURFACE\%20WATERS\%20ASSOCIAT ED\%20WITH\%20DIFFERENT\%20FORESTRY \%20MANAGEMENT\%20INTENSITIES'

Malone, R.W., S. Logsdon, M.J. Shipitalo, J. Weatherington-Rice and L. Ahuja et al., 2003. Tillage effect on macroporosity and herbicide transport in percolate. Geoderma, 116: 191-215. DOI: $10.1016 / \mathrm{S} 0016-7061(03) 001010$

Michael, J.L. and D.G. Neary, 1993. Herbicide dissipation studies in southern forest ecosystems. Environ. Toxicol. Chem., 12: 405-410. DOI: 10.1002/etc.5620120303

Neary, D.G., P.B. Bush and J.L. Michael, 1993. Fate, dissipation and environmental effects of pesticides in southern forests: A review of a decade of research progress. Environ. Toxicol. Chem., 12: 411-428. DOI: $10.1002 /$ etc.5620120304

Nicholas, J. and M. Larsson, 2000. Modeling Macropore Flow in Soils: Field Validation and Use for Management Purposes. In: Conceptual Models of Flow and Transport in the Fractured Vadose Zone. National Academy of Sciences Press, Washington, D.C. ISBN: 10: 0-309-07302-2, pp: 189-215.

Oregon State University, 1993. Extoxnet-Pesticide Information Profile-Metsulfuron-methyl. Cooperative Extension Offices of Cornell University, Michigan State University, Oregon State University and University of California at Davis. http://extoxnet.orst.edu/ 
Prater, J.L., 1981. Soil Survey of White and Van Buren County, TN. US Department of Agriculture, Washington, D.C. Sudocs: A57.38/42:G92. http://soildatamart.nrcs.usda.gov/manuscripts/TN6 04/0/whitevanburen.pdf

Radojevic, M. and V.N. Bashkin, 1999. Practical Environmental Analysis. 1st Edn., Royal Society of Chemistry, Cambridge, UK., ISBN: 10: 0854045945, pp: 466.

Shirmohammadi, A., W.G. Knisel, L.F. Bergstrom, R. Bengtson and A. Ward et al., 2001. GLEAMS Model. In: Agricultural Non-Point Source Water Quality Models: Their Use and Application, Southern Cooperative Series Bulletin, 398, John, E.P., L.T. Daniel and L.H. Rodney (Eds.). North Carolina State Univ., Raleigh, NC, USA., pp: 7083. ISBN: 1-58161-398-9
The Weather Underground, 2006. History and Almanac, Crossville, TN, Inc., http://www.wunderground.com/US/TN/Crossville. html\#History 